\title{
Taman Komunitas Dengan Pendekatan Green Architecture Di Kota Solo
}

\author{
Alvinda Saraswati, Musyawaroh, Hari Yuliarso \\ Program Studi Arsitektur \\ Fakultas Teknik \\ Universitas Sebelas Maret Surakarta \\ Email : alvindasaraswati846@gmail.com
}

\begin{abstract}
Public space is an urban facility that serves as a forum for interaction and recreational activities of the community. However, the existence of Solo City's public space which serves as an area of interaction, recreation society and urban green space become degraded. Until 2014 Solo City's public green space reached $12.02 \%$ of the total is to be achieved by $20 \%$. The impact of vandalism of Solo City's public space reducing facial aesthetics and lowering the interest of the public to visit. As a problem-solving strategies, takes a public space planning that can accommodate recreational activities and community interaction and optimize its potential as a green open space that can preserve environmental sustainability. With the phenomenon of people's appreciation of community interest and talent of Solo City is high enough, it can be a potential concept of public space that can accommodate groups of community interaction and public recreation. The formulation of the problem in this design is how to plan and design a community park as efforts increase green open space that can accommodate groups of community interaction and recreation community in Solo with Green Architecture approach. Thus it can be formulated Taman Komunitas planning objectives aligned with the Rencana Strategis (RENSTRA) Dinas Tata Ruang Kota Surakarta Tahun 2011-2015 to realize the addition of green open space which serves as the lungs of the city at the same time facilitate the activities of community interaction and recreation. Tangible public space planning to optimize its potential as a park with green open spaces are supported by a strategic approach to the concept of Green Architecture in order to achieve the target. The applied aspects of Green Architecture refers to the Greenship criteria set by the Green Building Council Indonesia. Four of these aspects include the right of land use, efficiency and energy conservation, water conservation, and health and comfort in the room. The application appears in the planning aspects of the design which utilizes the natural potential include the use of green roof, green walls, environmentally friendly materials, as well as planning refers to the Greenship benchmark..
\end{abstract}

Keywords: Community Park, Green Architecture, Green Open Space, Solo City

\section{PENDAHULUAN}

Ruang publik kota merupakan salah satu sarana perkotaan yang berfungsi sebagai wadah kegiatan interaksi dan rekreasi bagi masyarakat. Pengadaan ruang-ruang publik Kota Solo diwujudkan dengan perencanaan perbanyakan Ruang Terbuka Hijau (RTH) yang berfungsi sebagai paru-paru kota sekaligus ruang interaksi masyarakat dimuat dalam Rencana Strategis (RENSTRA) Dinas Tata Ruang Kota Surakarta Tahun 2011-2015. Pengadaan RTH dilandasi oleh UndangUndang No. 26 tahun 2007 tentang Penataan Ruang di mana diisyaratkan luas RTH minimal $30 \%$ dari luas wilayah perkotaan.

Hingga tahun 2014, RTH publik baru mencapai angka $12,02 \%$ dari total keseluruhan yang harus dicapai sebesar 20\% (BLH Kota Solo). Dari sembilan eksisting RTH Kota Solo (Kawasan pejalan kaki, Stadion Manahan, Taman Air Tirtonadi, Taman Balekambang, Taman Monumen 45 Banjarsari, Taman Satwa Taru Jurug, Taman Sekartaji, Taman Sriwedari, Taman Urban Forest Pucangsawit) beberapa di antaranya belum didukung dengan perencanaan kriteria taman dengan konsep bangunan hijau yang mendukung keberlangsungan lingkungan hidup maupun konsep Ruang Terbuka Hijau sebagai area peresapan. Rendahnya kesadaran masyarakat untuk saling menjaga dan merawat ruang publik menurunkan nilai keindahan dan kenyamanan sehingga mengurangi ketertarikan masyarakat untuk datang. Kemunculan 
tipologi ruang publik baru yaitu pusat perbelanjaan modern semakin menurunkan popularitas ruang publik Kota Solo.

Ruang publik yang direncanakan harus mengusung aspek universalitas, yaitu dapat memenuhi kebutuhan seluruh lapisan masyarakat baik kelas atas sampai bawah, pria-wanita, jenjang usia hingga perbandingan keadaan fisik seseorang (normal dan difabel) (Purwanta, 2004). Hal tersebut diwujudkan dengan perencanaan taman umum yang dapat dikunjungi oleh seluruh lapisan masyarakat tanpa membebani kemampuan finansial maupun fisik. Perencanaan taman harus didukung dengan konsep Green Architecture sehingga tercapai sasaran rencana DTRK untuk mewujudkan penambahan luas RTH publik Kota Solo.

Taman harus mampu bersaing menarik minat masyarakat terhadap tipologi ruang publik baru yaitu pusat perbelanjaan modern. Permasalahan tersebut dapat diselesaikan dengan mempertimbangkan fenomena serta potensi yang terjadi di Kota Solo. Fenomena keberadaan komunitas minat dan bakat tersebar di beberapa wilayah Kota Solo. Kegiatan komunitas dapat menjadi potensi yang akan menarik minat masyarakat. Apresiasi masyarakat yang tinggi pada kelompok komunitas terbukti dengan diadakannya acara-acara komunitas seperti Solo International Performing Arts, Solo Batik Carnival, Festival Keroncong Solo, Festival Kereta Kencana, dan sebagainya. Perwadahan kegiatan kelompok komunitas pada taman dapat menjadi potensi interaksi serta rekreasi bagi masyarakat Kota Solo.

Perwujudan taman yang mewadahi kegiatan interaksi dan rekreasi komunitas serta masyarakat dengan konsep Green Architecture diharapkan dapat mencapai sasaran Dinas Tata Ruang Kota Surakarta dalam Rencana Strategis Tahun 2011 - 2015 untuk mewujudkan perbanyakan RTH yang berfungsi sebagai paru-paru kota sekaligus ruang interaksi masyarakat.

\section{METODE}

A. Macam dan Teknik Pengumpulan Data Data yang dikumpulkan yakni data terkait proses perancangan taman komunitas seperti data lokasi dan tapak, data kegiatan dan kebutuhan ruang pada tinjauan preseden taman komunitas. Selain itu juga terdapat tinjauan pustaka terkait gubahan massa, sistem struktur, sistem utilitas, dan sistem sirkulasi pada taman yang berhubungan dengan strategi Green Architecture. Seluruh data tersebut diperoleh dari tinjauan pustaka serta wawancara kepada masyarakat dan pelaku kegiatan taman.

B. Analisis Perencanaan dan Perancangan Proses analisis melibatkan pengolahan data yang telah dikumpulkan. Analisis perencanaan dilakukan dengan mengidentifikasi permasalahan pada objek pengamatan yang kemudian diimbuhi dengan data literatur dan isu terkini sebagai upaya penyelesaian masalah.

Acuan yang digunakan dalam penyelesaian permasalahan yaitu dengan menerapkan pendekatan konsep Green Architecture dalam empat aspek Greenship yang diatur oleh Green Building Council Indonesia.

Hasil proses analisis merupakan bahan perancangan transformasi desain Taman Komunitas yang akan direncanakan.

C. Transformasi Desain

Proses transformasi desain secara umum mengacu pada empat aspek Greenship yaitu aspek tepat guna lahan, aspek efisiensi dan konservasi energi, aspek konservasi air, serta aspek kesehatan dan kenyamanan dalam ruang.

Proses transformasi meliputi penerjemahan hasil analisis perencanaan dan perancangan ke dalam output desain Taman Komunitas. Proses transformasi diawali dengan penentuan gubahan massa terhadap kegiatan interaksi dan rekreasi masyarakat serta kelompok komunitas. Selain fungsi perwadahan, pengolahan bentukan massa mengacu pada kriteria tolak ukur Greenship dengan mewujudkan penggunaan green roof, green walls, serta pemanfaatan potensi 
alam sebagai upaya pelestarian kelangsungan lingkungan hidup.

Analisis perencanaan dilakukan dengan mengidentifikasi masalah yang terdapat pada konsep perancangan taman komunitas dengan pendekatan konsep Green Architecture di Kota Solo yang diselesaikan dengan menerapkan kriteria Greenship oleh Green Building Council Indonesia serta digabungkan dengan standar perancangan taman oleh Time Saver Standard dan peraturan perundang-undangan Indonesia tentang pedoman penyediaan dan pemanfaatan ruang terbuka hijau.

Konsep Green Architecture yang diterapkan mengacu pada empat standar Greenship yaitu aspek tepat guna lahan, aspek efisiensi dan konservasi energi, aspek konservasi air, serta aspek kesehatan dan kenyamanan dalam ruang.

\section{ANALISIS}

A. Analisis Peruangan

Peruangan yang direncanakan sesuai fungsi dan kebutuhan dari pelaku kegiatan dan kegiatan taman komunitas yang direncanakan. Peruangan terbagi ke dalam lima blok yang dikelompokkan sesuai perwadahan kegiatan (Tabel 1).

1. Blok interaksi untuk mewadahi kegiatan interaksi seperti diskusi dan pameran oleh kelompok komunitas dan pengunjung umum.

2. Blok rekreasi untuk mewadahi kegiatan yang bersifat rekreatif yang menunjang kegiatan kelompok komunitas tertentu seperti area trek $B M X$ dan area skateboard. Blok rekreasi juga mewadahi kegiatan rekreatif di dalam taman pada umumnya.

3. Blok komersil untuk mewadahi kegiatan jual beli antara penjual dan pengunjung taman komunitas. Blok komersil juga mewadahi kebutuhan area makan dan hiburan panggung bagi pengunjung.

4. Blok pengelola untuk mewadahi kegiatan administratif dan pengelolaan taman komunitas.
5. Blok servis untuk mewadahi kegiatan penunjang taman komunitas.

Tabel 1.Kebutuhan Ruang

\begin{tabular}{|l|l|l|}
\hline PELAKU & $\begin{array}{c}\text { KEGIATA } \\
\text { N }\end{array}$ & PERUANGAN \\
\hline $\begin{array}{l}\text { Pengunjun } \\
\text { g Umum }\end{array}$ & $\begin{array}{l}\text { Berkumpul } \\
\text { Diskusi } \\
\text { Menonton } \\
\text { Komunitas }\end{array}$ & $\begin{array}{l}\text { Blok Interaksi } \\
\text { (ruang interaksi, } \\
\text { ampiteater, dan } \\
\text { panggung) }\end{array}$ \\
\cline { 2 - 3 } & $\begin{array}{l}\text { Kegiatan } \\
\text { Lain }\end{array}$ & $\begin{array}{l}\text { Blok Rekreasi } \\
\text { (trek BMX, trek } \\
\text { skateboard, trek } \\
\text { jogging, trek } \\
\text { sepeda, dan jalur } \\
\text { pejalan kaki) }\end{array}$ \\
\hline $\begin{array}{l}\text { Kelompok } \\
\text { Komunitas }\end{array}$ & $\begin{array}{l}\text { Berkumpul } \\
\text { Diskusi } \\
\text { Menonton } \\
\text { Komunitas }\end{array}$ & $\begin{array}{l}\text { Blok Interaksi } \\
\text { (ruang interaksi, } \\
\text { ampiteater, dan } \\
\text { panggung) }\end{array}$ \\
\cline { 2 - 3 } & $\begin{array}{l}\text { Kegiatan } \\
\text { Lain }\end{array}$ & $\begin{array}{l}\text { Blok Rekreasi } \\
\text { (trek BMX, trek } \\
\text { skateboard, trek } \\
\text { jogging, trek } \\
\text { sepeda, dan jalur } \\
\text { pejalan kaki) }\end{array}$ \\
\hline $\begin{array}{l}\text { Blok Komersil } \\
\text { (retail dan area } \\
\text { makan) }\end{array}$ \\
\hline $\begin{array}{l}\text { Penyewa } \\
\text { Komersil }\end{array}$ & Jual Beli & $\begin{array}{l}\text { Kantor Pengelola } \\
\text { Poks Tiket } \\
\text { Area Parkir } \\
\text { Pos Keamanan }\end{array}$ \\
\hline Servis & Pengelolaan & Penunjang \\
\hline
\end{tabular}

B. Analisis Lokasi

Proses pemilihan tapak disesuaikan dengan aspek tepat guna lahan yang diatur dalam kriteria Greenship oleh Green Building Council Indonesia.

1. Tujuan Mendapatkan lokasi kawasan dan lingkungan sebagai lokasi taman komunitas.

2. Dasar pertimbangan:

Proses analisis melibatkan data Rencana Tata Ruang Wilayah Kota Surakarta, pengamatan titik penting yang menjadi potensi keberadaan kelompok komunitas, tapak merupakan lahan non produktif, 
tapak berada di lingkungan ramai dan mudah dijangkau masyarakat, serta tapak dilengkapi oleh sarana dan prasarana kota.

\section{Analisis Pencapaian}

Pencapaian ke dalam bangunan harus mudah diakses, mudah dilihat dan memiliki sirkulasi yang aman akan menstimulus orang untuk masuk dalam area bangunan.

1. Tujuan: menentukan main entrance, side entrance, dan menentukan service entrance.

2. Dasar Pertimbangan: kemudahan akses, arus kendaraan dan potensi jalan, tingkat keamanan.

3. Proses analisis

\section{Main Entrance}

Diakses langsung dari jalan utama dengan mempertimbangkan kebutuhan jalur hijau untuk mengurangi kepadatan kendaraan masuk.

Side Entrance

Diakses langsung dari jalan lingkungan terpadat setelah jalan utama untuk memudahkan pengunjung mencapai tapak dari dua arah.

\section{Service Entrance}

Diakses langsung dari jalan lingkungan yang sepi dan tidak terlihat dari bagian muka tapak (Gambar 1).

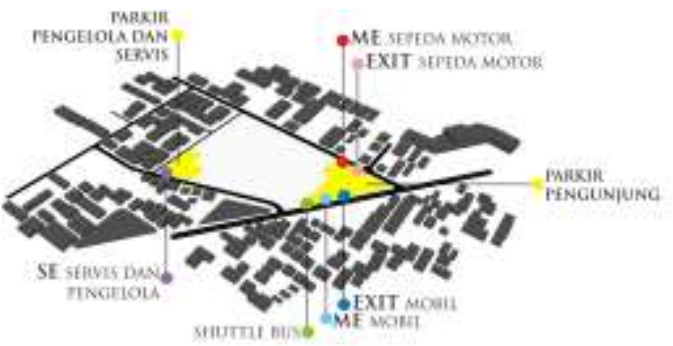

Gambar 1. Analisis Pencapaian

D. Analisis Pemintakatan

Pemintakatan berfungsi untuk mengelompokkan jenis kegiatan yang saling berhubungan untuk mempermudah pelaku kegiatan mengakses setiap bagian taman (Gambar 2).

1. Tujuan: menentukan mintakat berdasarkan jenis kegiatan dan kelompok ruang.

2. Dasar pertimbangan: analisis pemetaan kelompok kegiatan sejenis.

3. Proses analisis: persyaratan ruang, kelompok kegiatan sejenis dan analisis pengolahan tapak.

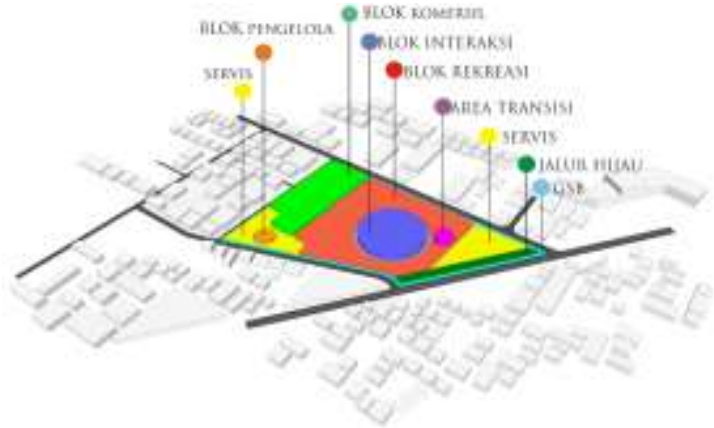

Gambar 2. Analisis Pemintakatan

E. Analisis Bentuk dan Tampilan

Bangunan

1. Analisis Bentukan Massa

Massa utama merupakan bangunan interaksi dan ampiteater dengan pola melingkar (Gambar 3). Pola melingkar berpusat pada panggung pertunjukkan ampiteater. Pertunjukkan pada ampiteater merupakan daya tarik utamadari area interaksi.

Bangunan interaksi direncanakan memiliki ketebalan massa bangunan yang tipis dengan komposisi bentuk linier (Gambar 4) untuk mengoptimalkan masuknya cahaya matahari dan sirkulasi angin sebagai respon dari efisiensi energi listrik yang digunakan bangunan. Bentukan massa tipis bertujuan agar bangunan interaksi tidak menggunakan mesin pendingin ruang buatan (air conditioner). Komposisi linier pada bentukan massa bangunan mempengaruhi kesederhanaan pola peruangan di dalam bangunan blok interaksi. 


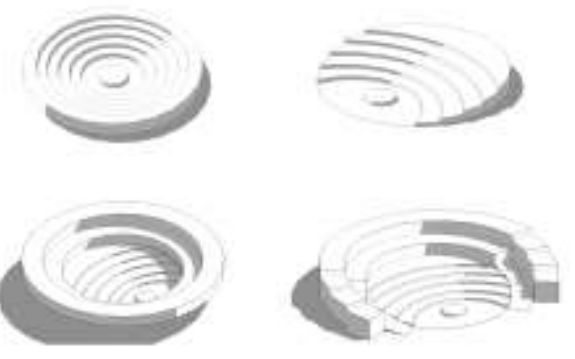

Gambar 3. Transformasi Massa Bangunan Interaksi dan Ampiteater

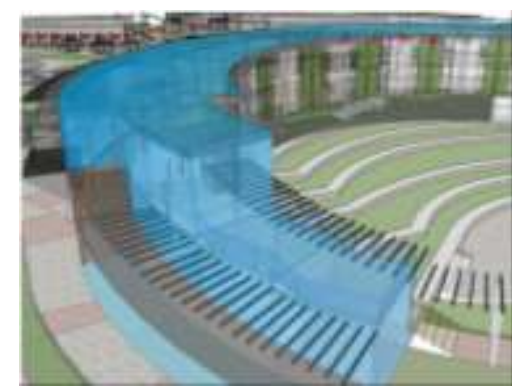

Gambar 4. Bentukan Massa Bangunan Interaksi

Massa sekunder merupakan kelompok bangunan komersil (Gambar 5). Bentuk dasar segiempat disusun secara linier dengan ketebalan massa tipis untuk mengoptimalkan masuknya cahaya matahari dan sirkulasi angin.

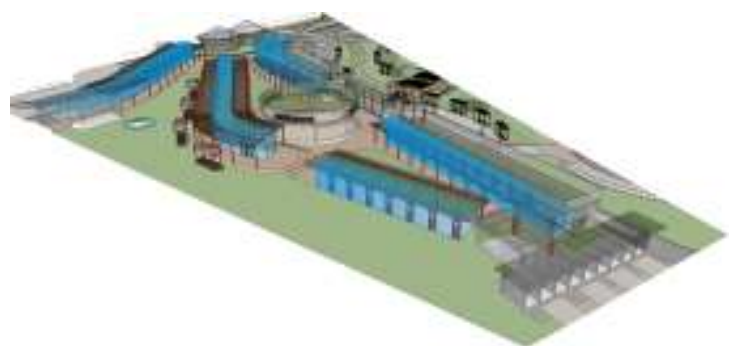

Gambar 5. Bentukan Massa Bangunan Komersil

2. Tampilan Bangunan

Tampilan bangunan pada massa utama dan sekunder harus mendukung konsep Green Architecture. Dasar pertimbangan pemilihan tampilan yaitu aspek estetika, akses cahaya matahari, akses angin dan udara, kebisingan, akses view keluar ruang, dan aspek kenyamanan dalam ruang. Berdasarkan pertimbangan tersebut, fasad bangunan menerapkan aplikasi green walls dan perforated panel. Green walls digunakan pada fasad bangunan utama sebagai tabir sinar matahari dan insulasi termal udara luar bangunan. Aplikasi green walls yang digunakan berupa media tanam berjenis pocket nylon planter yang mudah dipasang pada dinding luar bangunan utama (Gambar 6). Perforated panel diapikasikan sebagai pengganti dinding terluar bangunan memiliki kelebihan untuk memberikan view dalam bangunan keluar bangunan, memasukkan angin dan udara melalui lubang panel, serta memasukkan cahaya matahari (Gambar 7). Perforated panel yang digunakan berbahan baja galvanis untuk menjaga ketahanan serta mengurangi pembuangan karbon akibat kegiatan penggantian, pemasangan kembali, dan transportasi pengiriman panel baru.

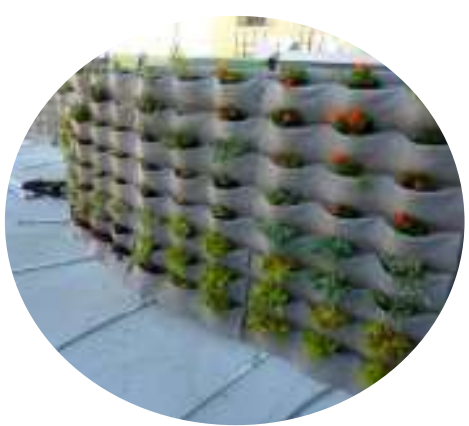

Gambar 6. Pocket Nylon Planter (sumber: $\underline{w w w . p l a n t s o n w a l l s . c o m})$

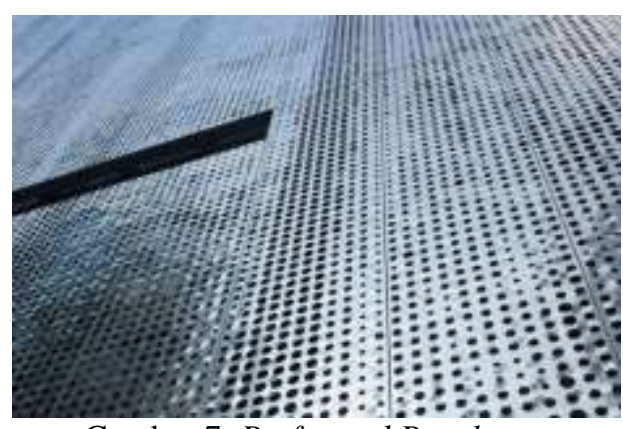

Gambar 7. Perforated Panels

(sumber: www.azahner.com) 
F. Analisis Sirkulasi dan Tata Lansekap

1. Sirkulasi antar blok pada taman komunitas yakni konsep sirkulasi hub and spoke. Konsep sirkulasi hub and spoke (www.interthemepark.com) terlihat seperti roda sepeda yang menghubungkan area utama dalam taman $(h u b)$ melalui suatu jalur (spoke) menuju ke beberapa bagian taman lain. Pola sirkulasi ini efisien untuk menjangkau setiap blok yang tersebar pada taman komunitas. Pertemuan pada jalur sirkulasi hub and spoke direncanakan atrium sebagai area transisi yang dapat dijangkau pengunjung untuk beristirahat.

Jalur sirkulasi yang direncanakan pada taman komunitas terbagi menjadi jalur pejalan kaki, jalur sepeda, jalur jogging, dan jalur mobil listrik. Mendorong penggunaan sepeda bagi pengunjung didukung dengan pengadaan parkir sepeda yang aman sebanyak satu unit parkir per 20 pengguna gedung hingga maksimal 100 unit parkir sepeda dan tersedianya shower sebanyak 1 unit untuk setiap 10 parkir sepeda (Greenship, 2012).

Respon terhadap kenyamanan pengunjung lansia dan anak anak, direncanakan mobil listrik yang dapat digunakan sebagai akses mengelilingi taman.

2. Pengolahan lansekap dilakukan untuk membantu mewujudkan konsep Green Architecture pada taman komunitas. Lansekap berfungsi sebagai area peresapan serta media tumbuhnya jenis jenis vegetasi.

a. Pengolahan sirkulasi lansekap menggunakan material ramah lingkungan seperti paving block dan material alami seperti batu alam, rumput, dan air yang mendukung konsep Green Architecture. Sirkulasi pedestrian, jogging, dan sepeda di dalam taman menggunakan kombinasi material paving block dan aspal. Sirkulasi taman dilengkapi dengan perencanaan drainase jalan untuk meneruskan laju air hujan yang tidak terserap oleh aspal.

b. Pengolahan elemen bangku taman sebagai area teduh pengunjung dilengkapi dengan shading penghalau matahari sebagai respon strategi Green Architecture. Desain lansekap pada sirkulasi pejalan kaki menunjukkan adanya pelindung dari panas akibat radiasi matahari dan terpaan angin kencang (Greenship, 2012).

c. Pengolahan softscape pada lansekap taman komunitas mempertimbangkan fungsi vegetasi yang diatur dalam Peraturan Menteri PU No. 5/PRT/M/2008 mengenai Ruang Terbuka Hijau (RTH) Pasal 2.3.1 tentang Kriteria Vegetasi untuk RTH Taman dan Taman Kota.

\section{G. Analisis Struktur}

1. Upper structure

Pemilihan sistem struktur yang digunakan berdasarkan pertimbangan:

a. Sistem merupakan sistem yang mampu bertahan dalam jangka waktu yang lama.

b. Pemilihan material memiliki jejak karbon rendah dan menggunakan material lokal.

Pada area upper structure, bangunan taman menggunakan green roof sebesar 50\% dari luas atap yang tidak digunakan untuk mechanical electrical (Greenship, 2012). Terdapat aplikasi pergola tanaman yang diaplikasikan pada bukaan sebagai strategi shading bangunan untuk mengurangi radiasi sinar matahari. 
2. Super structure

Pemilihan sistem struktur yang digunakan berdasarkan pertimbangan:

a. Sistem merupakan sistem yang mampu bertahan dalam jangka waktu yang lama.

b. Pemilihan material memiliki jejak karbon rendah dan menggunakan material lokal.

c. Mendukung konsep Green Architecture.

Pada area super structure, bangunan taman komunitas menggunakan aplikasi green wall sebagai material penutup dinding terluar bangunan.

\section{H. Analisis Utilitas}

1. Utilitas Pencahayaan

Taman komunitas merencanakan penggunaan pencahayaan alami yang optimal serta menerapkan penggunaan bukaan yang efisien untuk mengurangi konsumsi energi (Greenship, 2012). Pencahayaan buatan menggunakan LED yang dapat mengurangi penggunaan listrik sebesar 9\% (Setyawan, 2012).

2. Utilitas Penghawaan

Penghawaan alami pada kantor pengelola, retail, dan area interaksi indoor melalui perencanaan bukaan yang dapat meneruskan laju angin dan menyejukkan ruangan, serta meletakkan elemen penyejuk di sekitar bangunan seperti kolam dan vegetasi. Merespon pertimbangan kesehatan pengunjung pada taman, maka direncanakan untuk memasang papan tanda dilarang merokok yang tersebar di seluruh area taman, area indoor maupun outdoor (Greenship, 2012).

3. Utilitas Sistem Sanitasi

a. Sumber air bersih berasal dari PDAM dan sumur buatan.

b. Penggunaan seluruh air bekas pakai (grey water) yang telah di daur ulang digunakan untuk kebutuhan sistem flushing dan pengairan lansekap. c. Penggunaan air hujan yang ditampung pada bak penampungan hujan untuk kebutuhan flushing dan pengairan lansekap.

d. Strategi perluasan peresapan air hujan sebasar 42 kali lipat dengan pembuatan biopori (www.biopori.com).

4. Utilitas Sistem Pembuangan dan Pengolahan Sampah

Pemisahan jenis sampah organik dan anorganik dengan menyediakan dua jenis bak sampah disebar pada taman komunitas. Sampah organik akan diolah pada biodigester yang akan menghasilkan output pupuk kompos untuk vegetasi taman.

\section{KESIMPULAN (KONSEP DESAIN)}

Konsep rancangan taman komunitas mengacu pada kriteria Green Architecture yang diatur dalam Greenship oleh Green Building Council Indonesia. Aspek kriteria yang diterapkan meliputi tepat guna lahan, efisiensi dan konservasi energi, konservasi air, serta kesehatan dan kenyamanan dalam ruang.

Dari hasil analisa serta hasil korelasi dari beberapa data di atas, maka diperoleh hasil berupa rancangan Taman Komunitas dengan Pendekatan Konsep Green Architecture di Kota Solo sebagai berikut.

Lokasi : Jl. Jendral Ahmad Yani

Luas Lahan $\quad: 28.000 \mathrm{~m}^{2}$

Luas Bangunan : $2.580 \mathrm{~m}^{2}$

Daya Tampung : 500 orang

Kegiatan : Ruang Publik

Sebagai sebuah ruang publik yang berfungsi untuk mewadahi kegiatan interaksi dan rekreasi masyarakat, Taman Komunitas direncanakan untuk memenuhi kebutuhan tersebut. Taman Komunitas hadir tidak hanya sebagai perwadahan ruang publik bagi masyarakat dan komunitas. Pendekatan Green Architecture yang diterapkan pada perencanaan dan perancangannya sebagai upaya pengembangan potensi Ruang Terbuka Hijau yang berfungsi sebagai paru-paru kota sekaligus melestarikan keberlangsungan lingkungan hidup. Desain bangunan pada Taman Komunitas dirancang untuk memenuhi kriteria Greenship sebagai tolak ukur tingkatan 
Green Architecture diantaranya penggunaan green roof pada struktur atap bangunan (Gambar 8).

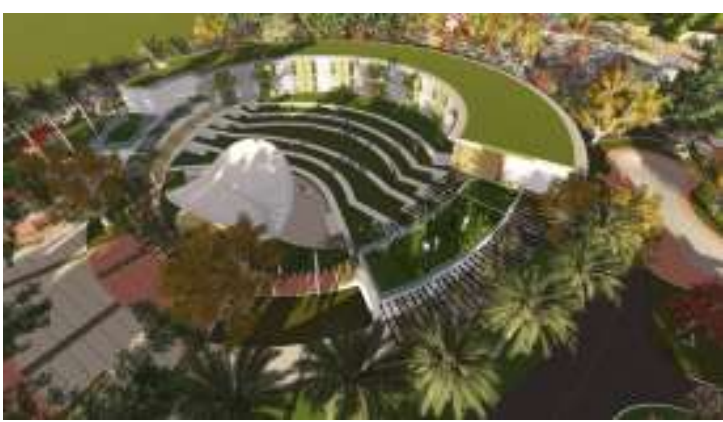

Gambar 8. Green Roof pada Atap Blok Interaksi

Perwujudan sarana dan prasarana penunjang kebutuhan interaksi dan rekreasi masyarakat dan kelompok komunitas muncul pada pengadaan area komersil (Gambar 9) dan area trek sepeda $B M X$ (Gambar 10) di dalam Taman Komunitas.

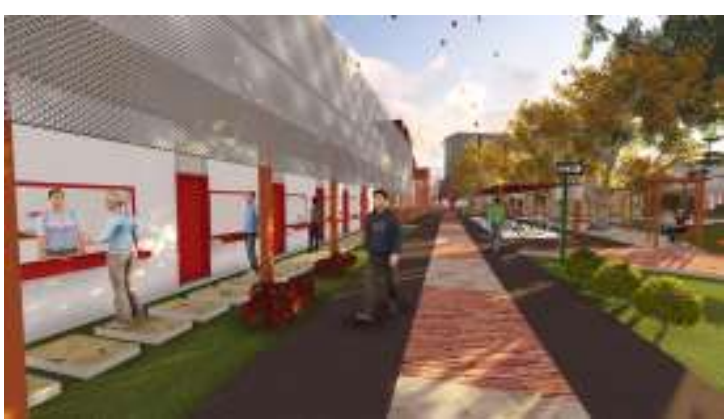

Gambar 9. Area Komersil

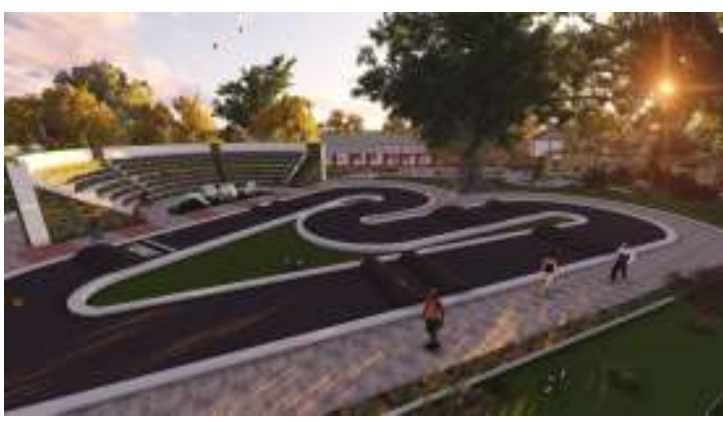

Gambar 10. Trek Sepeda $B M X$

\section{REFERENSI}

Green Building Council Indonesia. 2012.

Greenship untuk Gedung Baru Versi 1.1.

Jakarta: Departemen Rating

Development Green Building Council

Indonesia.
Purwanta, Setia Adi. 2004. Menunbuhkan Perspektif Difabel untuk mewujudkan Masyarakat Inklusif dalam Pokok-pokok pikiran Dr. Mansour Fakih: Refleksi Kawan Seeperjuangan. Jakarta: Sigap dan Oxfam.

Setyawan, I Putu Gde Weda. 2012.

Manajemen Energi di Rumah Sakit Surya Husada Denpasar. Bali: Universitas Udayana.

http://www.azahner.com/portfolio/thefairmont

http://www.biopori.com

http://www.interthemepark.com

http://www.plantsonwalls.com/Florafelt-4Pocket-Vertical-Garden-Planterp/f4.html 